Article

\title{
THE DREAM OF PACIFICATION: ACCUMULATION, CLASS WAR, AND THE HUNT
}

\author{
MARK NEOCLEOUS \\ Department of Politics and History, Brunel University, UK ${ }^{1}$
}

\begin{abstract}
This article argues that the category 'pacification' offers the critique of security a means of thinking through the connection between war, police and accumulation. Pacification is a process in which the war power is used in the fabrication of a social order of wage labour. This aligns the war power with the police power, and suggests that their interconnection might be understood through the lens of pacification. The article explores this through one of the mechanisms through which the war power and police power combine: the hunt. Capital rests on the hunt: the hunt for vagabonds, beggars, enemies, criminals, terrorists. Behind this hunt lies capital's original demand, Let there be Accumulation! 'Pacification' is a category that helps us make sense of the way the state responds to this demand.
\end{abstract}

\section{Keywords}

Pacification, primitive accumulation, manhunt, war, police, police powers

In the chapter on the genesis of industrial capital in Volume 1 of Capital, Marx writes:

The discovery of gold and silver in America, the extirpation, enslavement and entombment in mines of the indigenous population of that continent, the beginnings of the conquest and plunder of India, and the conversion of Africa into a preserve for the commercial hunting of black skins, are all things which characterize the dawn of the era of capitalist production. These idyllic proceedings are the chief moments of primitive accumulation. Hard on their heels follows the commercial war of the

\footnotetext{
${ }^{1}$ Mark Neocleous is Professor of the Critique of Political Economy in the Department of Politics and History at Brunel University in the UK. He is the author of several books including, most recently, Critique of Security (2008), and co-editor (with George Rigakos) of Anti-security (2011). His new book, War Power, Police Power, is forthcoming in 2014. He is a member of the Editorial Collective of Radical Philosophy. 
European nations, which has the globe as its battlefield ... These different moments are systematically combined together at the end of the seventeenth century in England; the combination embraces the colonies, national debt, the modern tax system, and the system of protection. These methods depend in part on brute force, for instance the colonial system. But they all employ the power of the state, the concentrated and organized force of society, to hasten, as in a hothouse, the process of transformation of the feudal mode of production into the capitalist mode, and to shorten the transition. Violence is the midwife of every old society which is pregnant with a new one. It is itself an economic power (Marx, 1976, 9156).

Marx here highlights the fact that capitalism is not a spontaneous order and that, in contrast to the myth of an idyllic origin of private property, in actual history violence plays a central role. What is at stake in Marx's discussion is the constitution of bourgeois order through what Marx calls 'primitive accumulation': the use of force and violence in separating people from a means of subsistence other than the wage. I want to suggest that the insight Marx here offers into the violence of accumulation is one that lies at the heart of the process of pacification.

In a previous essay trying to help map out the terrain of a project organised around the idea of anti-security (Neocleous, 2011a; also 2010), I argued that for tactical purposes critical theory really needs to re-appropriate the term 'pacification'. The central argument was that we need to grasp security as pacification. I suggested that whereas for most people 'pacification' is associated with the actions of colonizing powers, has a close connection to counter-insurgency tactics and is therefore widely understood as the military crushing of resistance, an examination of the theory and practice of pacification reveals a far more 'productive' dimension to the idea. 'Productive' in that what is involved is less the military crushing of resistance and more the fabrication of order, of which the crushing of resistance is but one part. This is why the key theorists of pacification, from Machuca in the late-sixteenth century, through to General Thomas-Robert Bugeaud, General Galliéni, Lieutenant Colonel Lyautey in the nineteenth century, taking in Roger Trinquier and David Galula in the twentieth century, all talk about pacification as a war to build rather than destroy. It is also why the key practice of pacification is nothing less than a feat of enormous social engineering to (re)build a social order. And what is to be built in this new order is a secure foundation for accumulation.

This image of pacification aligns it with what has historically been understood as the police project - the fabrication of social order organised around the administration of wage labour - and connects very closely with the fact that the critique of security reads and treats security as a police mechanism (Neocleous, 2000; 2008; Neocleous and Rigakos, 2011). What this means, in turn, and especially so given the connections 
between pacification and war, is that to employ the category 'pacification' critically we are compelled to connect the police power to the war power. Indeed, as a critical concept 'pacification' insists on conjoining war and police in a way which is fundamentally opposed to the mainstream tendency that thinks of war and police as two separate activities institutionalized in two separate institutions (the military and the police). This ideological separation has had a debilitating effect on radical scholarship within the academy, since it has imposed on scholars a banal dichotomy of 'models', such as the 'criminological model' versus the 'military model', and generated a set of what are ultimately liberal concerns, such as the 'militarization of the police' and the 'policization of the military' or the coming together of 'high intensity policing' with 'low-intensity warfare'. Such models and concerns obscure the unity of state power and act as a blockage on radical thought.

In other words, if radical theory in general and the politics of anti-security in particular are to get any kind of purchase on pacification as an idea then we must address the ways in which it invokes the conjunction of war and police. As much as the art of war is the art of the polis - the polis originates as a guild of warriors, as Weber $(1978,1359)$ points out - so too the polis connotes police as well as city. 'Pacification' is intended to capture the way in which war and police are always already together, the way they operate conjointly under the sign of security, and the way in which this operation is entwined with the process of accumulation. In other words, 'pacification' is intended to grasp a nexus of ideas - war-police-accumulation - in the security of bourgeois order. All of which is to say that from the perspective of the critique of security, it is impossible to understand the history of bourgeois society without grasping it as a process of pacification in the name of security and accumulation.

Starting with Marx's category of 'primitive accumulation', which I believe helps us understand the police power at the heart of class war, the intention in this article is to make 'pacification' a central category for our understanding of that war. To stress the 'active' or 'productive' nature of pacification, the article places the manhunt at the heart of the process, seeking to posit the hunt for workers, for criminals, for terrorists, and for the enemies of order as integral to the most significant demand imposed on human beings in the last 500 years: let there be accumulation!

\section{Let There Be Workers!}

Marx begins his analysis of primitive accumulation by claiming that it plays the same role in political economy as primitive sin does in theology.

Adam bit the apple, and thereupon sin fell on the human race. Its origin is supposed to be explained when it is told as an anecdote about the past. 
Long, long ago there were two sorts of people: one, the diligent, intelligent and above all frugal elite; the other, lazy rascals, spending their substance, and more, in riotous living... Thus it came to pass that the former sort accumulated wealth, and the latter sort finally had nothing to sell but their own skins. And from this primitive sin dates the poverty of the great majority who, despite all their labour, have up to now nothing to sell but themselves (Marx, 1976, 873).

Marx's ironic turn of phrase is designed to open up the important move he makes, one in which he shifts from mocking the concept as used by Smith to using it as a serious concept in its own right.

For Marx, primitive accumulation is the process that constitutes capitalist social relations as the separation of the bulk of the population from the means of production (Marx, 1973, 489). This process is of obvious crucial historical importance, since without separating workers from the means of production capital could not have come into being; without such separation there could be no capitalist accumulation. The secret of the expression of value lies in how capital manages labour, and that reveals in turn the fundamental secret of accumulation, namely 'the appropriation of unpaid labour'. In other words, the underlying principle of accumulation is that capital must have at its disposal the unpaid labour of workers. Marx restates the key point time and again: capitalist accumulation has for its fundamental condition the expropriation of the worker (Marx, 1976, 152, 168, 672, 743, 748, 793, 613, 940). ${ }^{2}$ This is why capital constantly seeks to remove all means of subsistence other than the wage, why it always searches for ways to force down wages, and why it has to permanently discipline people into and in their role as productive and efficient workers.

One of the purposes of Marx's concept of primitive accumulation is to show that in contrast to the story told in political economy, where accumulation is simply assumed to have emerged in peaceful and idyllic conditions, in actual history violence is integral to the process. This violence turns out to be central to the argument through the whole of Capital, but Marx addresses it at length in the chapter on 'the genesis of industrial capital' where, as we have observed, he connects the extirpation and enslavement of human beings during the conquest of the colonies to the wider commercial war of the European nations: the colonies, the national debt, the modern tax system and the whole system of protection depend on the coercive power of the state to transform the feudal mode of production into the capitalist mode. Capital comes into the world 'dripping from head to toe, from every pore, with blood and dirt' (Marx, 1976, 926). Capital is fabricated, and it is fabricated through sheer force. Capital demands 'Let there be workers!' (Marx, 1973,

${ }^{2}$ I have explored the importance of this in Neocleous, 2012, pp. 941-62, on which this section is based. 
506n), and to this demand the state responds using every means of violence at its disposal.

Two points to note here about this mechanism by which people are made to work within the conditions posited by capital. The first is that it is a permanent feature of capitalism. This permanence is important, since it is easy to treat primitive accumulation as a concept applicable solely to the period of transition from feudalism to capitalism - a view encouraged by the fact that the discussion of primitive accumulation requires a discussion of historical enclosures and colonialism and the convention of translating 'ursprüngliche' as 'primitive' rather than 'original' or 'previous' ('ursprüngliche' being Marx's translation of Smith's 'previous', which those translating Marx's work into English rendered as 'primitive'). In fact, we need to understand primitive accumulation as the foundation of capital not just historically but permanently: capital presupposes the divorce of workers from the conditions of the realization of their labour, and as soon as it is able to stand on its own two feet capital reproduces this divorce over and again. Hence Marx's claim that 'accumulation merely presents as a continuous process what in primitive accumulation appears as a distinct historical process' (1972, 272, emphasis added). In other words, 'primitive accumulation' is not a term describing a period in the emergence of capitalist relations or a transitory phenomenon characteristic of the 'prehistory' of capital but, rather, captures capitalism's need to permanently form markets and re-create its own labour supply. If the separation of labourers from the conditions of labour independent of capital is (not just was) the social constitution of capitalist social relations, then we need to understand primitive accumulation not as a historical process exhausted by the consolidation of capital but, rather, a permanent feature of accumulation (Luxemburg, 1913; Balibar, 1970; Midnight Notes Collective, 1992, 318).

The second point to note about the process is that it is a form of war. Not 'war' in the classical military sense of organised inter-state violence, but, rather, a 'social war' or 'civil war'. In a speech at Elberfeld in 1845 Frederick Engels commented on 'present-day society, which ... produces a social war of all against all' (Engels, 1975a, 248). This was a major theme of The Condition of the Working Class in England, published the same year, which describes 'the social war, the war of each against all'. Everywhere is barbarous indifference, hard egotism and nameless misery: 'every man's house is a state of siege, everywhere reciprocal plundering under the protection of the law', meaning that 'everywhere [is] social warfare'. Such comments appear as a gloss on the perpetual war of the state of nature as described by Hobbes, but Engels points to the class dimension of this war. 'Let us proceed to a more detailed investigation of the position in which the social war has placed the non-possessing class', an investigation which takes in the miserable condition of the working class, the deaths from overwork and malnutrition, and the use of the law against any attempt on the part of the working class to resist such conditions. 'Is this social war, or is it not?' asks Engels (Engels, 1975b, 329, 331, 554, 502, 
512). Marx likewise refers to 'civil war in its most terrible aspect, the war of labour against capital' $(1977,147)$, and in Capital writes of the struggles over the working day as part of a 'protracted and more or less concealed civil war between the capitalist class and the working class' (Marx, 1976, 409, 412-3). As joint-authors of the Manifesto of the Communist Party Marx and Engels also write of the 'more or less veiled civil war' that takes place in bourgeois society with the development of the proletariat (Marx and Engels, 1984, 495).

It is too easy to say that when Marx and Engels use the term 'war' in these ways they do so in a rhetorical sense (Malesevic, 2010, 22) but, much as Marx and Engels do delight in more than the occasional rhetorical flourish, their claims about the social war are meant to be taken seriously. Hence when in Capital Marx comments that 'force is the midwife of every old society which is pregnant with a new one', and that force 'is itself an economic power' $(1976,916)$, the term Marx uses is Gewalt, better understood as 'violence', and he is describing the process which underpinned the rise of capital and created the proletariat. The violence is a form of war.

What Marx is talking about when he is describing primitive accumulation, then, is class war. Now, as well as brute force, two of the main weapons used by the ruling class in this war are law and police: the Acts outlawing vagabondage, begging, wandering, and myriad other 'offenses' on the one hand, and the enclosure of the commons through the theft and transformation of the commons into private property on the other. This is the 'bloody legislation' against the expropriated which transforms peasants into vagabonds and paupers and then transforms vagabonds and paupers into good workers, and is integral to Marx's analysis of accumulation. Marx cites an Act passed under Henry VIII in 1530: 'Beggars who are old and incapable of working receive a beggar's licence', but 'sturdy vagabonds' are to be beaten and punished. 'They are to be tied to the cart-tail and whipped until the blood streams from their bodies, that they are to swear on oath to go back to their birthplace or to where they have lived the last three years and to "put themselves to work"'. A later Statute under Henry VIII repeated and strengthened this with new clauses: 'For the second [offense] for vagabondage the whipping is to be repeated and half the ear sliced off; but for the third relapse the offender is to be executed as a hardened criminal and enemy of the common weal'. A further Act of 1547 ordained that if anyone refuses to work 'he shall be condemned as a slave to the person who has denounced him as an idler'.

The master ... has the right to force him to do any work, no matter how disgusting, with whip and chains. If the slave is absent a fortnight, he is condemned to slavery for life and is to be branded on forehead or back with the letter S; if he runs away thrice, he is to be executed as a felon. The master can sell him, bequeath him, let him out on hire as a slave, just as 
any other personal chattel or cattle. If the slaves attempt anything against the masters, they are also to be executed. Justices of the peace, on information, are to hunt the rascals down. If it happens that a vagabond has been idling about for three days, he is to be taken to his birthplace, branded with a red-hot iron with the letter $\mathrm{V}$ on the breast and be set to work, in chains, in the streets or at some other labour. If the vagabond gives a false birthplace, he is then to become the slave for life of this place, of its inhabitants, or its corporation, and to be branded with an S. All persons have the right to take away the children of the vagabonds and keep them as apprentices, the young men until they are 24, the girls until they are 20. If they run away, they are to become, until they reach those ages, the slaves of their masters, who can put them in irons, whip them, etc. if they like ... The last part of this statute provides, that certain poor people may be employed by a place or by persons who are willing to give them food and drink and to find them work. Slaves of the parish of this kind were still to be found in England in the mid nineteenth century under the name of 'roundsmen'.

Marx continues with an Act of 1572:

Unlicensed beggars ... age are to be severely flogged and branded on the left ear unless some one will take them into service for two years; in case of a repetition of the offence ... they are to be executed, unless some one will take them into service for two years; but for the third offence they are to be executed without mercy as felons.

Remaining with the English case, Marx goes on:

James 1: Any one wandering about and begging is declared a rogue and a vagabond. Justices of the peace in Petty Sessions are authorised to have them publicly whipped and to imprison them for six months for the first offence, and two years for the second. Whilst in prison they are to be whipped as much and as often as the justices of the peace think fit... Incorrigible and dangerous rogues are to be branded with an $\mathrm{R}$ on the left shoulder and set to hard labour, and if they are caught begging again, to be executed without mercy.

And on it goes through the development of the criminal law. Note that the creatures who would haunt the bourgeois mind at this point historically, the vagabonds, paupers, beggars, criminals, as well as their social cousins who will later emerge (the 'undeserving 
poor', the 'skivers', the 'squeegee merchants', the 'feral youth', the 'delinquents'), will be the ones on which war will be declared time and again, but are the subject of police power, by definition, for they are the enemies of order. Yet as we know, 'police' at this time was concerned not just with order in general, but referred to 'a bundle of measures that made work possible and necessary to all those who could not possibly live without it', as Foucault puts it in History of Madness (2006, 62; also Neocleous, 2000). This bundle of police measures in aid of war and war measures in aid of police to make work possible and necessary - that is, to put the poor to work, to make the working class work and thus, in effect, to make the working class - is the state's response to the demand 'Let there be Workers!'. It is nothing less than the secret of accumulation. Might this also be the secret of pacification?

\section{Let's Go Hunting!}

In the context of his discussion of police in History of Madness, Foucault describes the 1656 Edict which established the Hôpital Général. Pointing out that the institution was expected to 'prevent begging and idleness, the sources of all disorder', Foucault cites Paragraph 9 of the Edict, which forbade 'all persons ... to beg in the city and outskirts of Paris, or in the churches, at the doors of churches, at the doors of houses or in the streets, or anywhere else, publicly or in private, by day or by night ... on pain of whipping for a first offence, and the galleys for men and boys upon a second offence'. The Edict was passed on 27 April, 1656, and Foucault notes that two weeks later the militia of the Hôpital Général 'went out hunting for beggars for the first time, and brought them back to the different buildings of the Hospital' (Foucault, 2006, 62-4). Foucault does not make much of this, yet it contains an important observation: the hunting for beggars. Elsewhere he describes the 'great police sorting out process' which began with 'the hunting down of vagrants, beggars, the idle' (Foucault, 1996, 83). ${ }^{3}$ We have also earlier cited Marx quoting the Act of 1547 to the effect that 'Justices of the peace, on information, are to hunt the rascals down' as well as his description of Africa as a preserve for the 'hunting of black skins'. Through the lens of police (Foucault) and the lens of accumulation (Marx) we are alerted to nothing less than the world historical importance of the manhunt.

'Governments mounted special searches or manhunts for vagrants', notes A. L. Beier in his history of vagrancy law.

The Statute of Winchester (1285) had required regular round-ups of felons in towns, and there were frequent searches for vagrants in London from 1514 and about the same time in some provincial towns. But national

\footnotetext{
${ }^{3}$ He makes a similar observation in Discipline and Punish (Foucault, 1977, 88), but again does not make a great deal of it.
} 
campaigns were seemingly first instituted under the Tudors. The Vagrancy Act of 1495 ordered [searches and round-ups] in all the towns and villages of the realm, as did a proclamation of 1511 and another of 1530. The poor law of 1536 also commanded officials to conduct nightly and daily 'privy or secret' searches for 'all rufflers, sturdy vagabonds and valiant beggars', and a new Act in 1610 established regular swoops for the first time (1985, 155).

As Beier notes about England, and as others have noted about such hunts in other European cities (for example, see Geremek, 1994, 215), the logic was driven by the very fact of vagrancy itself, a protean concept to describe social disorder in all its manifestations: the status of 'vagrancy' was a criminal one merely because it was at odds with the established order, and this condition affected all those beggars, hawkers, travellers, peddlers, harlots, cutpurses, minstrels and other masterless men and women whose status and condition looked like vagrancy to the ruling class. As such, it was also decidedly political and thus the tensions surrounding it intensified during periods of unrest. Hence in England the periods of intense hunting for vagabonds of 1560-72 and 1631-9 followed rebellions of a more direct political nature (Beier, 1985, xxii, 4, 152, 1556). In this regard, it is worth registering that the Old French term Meute referred to 'the hunt' but also connoted 'rebellion or insurrection' (Canetti, 1962, 97).

Such searches and roundups constituted the foundation of police power. Or, to put that another way, the police power was forged through the hunting of the idle poor, the beggar and the vagabond (Chamayou, 2012, 78). This hunting of beggars, vagabonds and the idle needs to be set in a wider context, one that alludes more directly to the police power in the making of the working class.

We have become accustomed to thinking in terms of strict categorizations of the historical forms of labour. These are usually 'slave', 'serf, 'wage-labourer', but often also understood as 'free' versus 'coerced'. In fact, various forms and degrees of contractual ('free') and yet coerced ('unfree') labour existed as late as the late-nineteenth century, in western industrialized nations as well as the colonies. There are three points to be made in this regard.

First there is the fact that the distinction between servitude and slavery was never clear. When Caliban in Shakespeare's The Tempest is referred to as a 'slave' despite being a 'servant' the slippage is not accidental. Likewise, in the work of a key bourgeois thinker such as John Locke, one finds that the distinction between slave and servant is made yet keeps breaking down, with Locke sometimes using the second term to refer to the slave proper. He speaks of a Planter's 'Power in his Family over Servants, born in his House, and bought with his Money' (Locke, 1988, 131). Blackstone in his Commentaries on 
English Law insists that there is no room in English law for 'absolute slavery' yet allows for forms of compulsory labour which appear to be a kind of not-quite-absolute-slavery.

Second, this oscillation between slavery and servitude is also a reflection of the extent to which degrees of 'quasi-slavery' continued to exist, partly a remnant of villeinage, partly an outcome of the law failing to distinguish theoretically between a slave and a serf, and partly due to the various Vagrancy Acts which facilitated the idea of slavery as a form of punishment. The English Vagrancy Act of 1547, for example, one of the harshest of Tudor laws and cited by Marx to that effect, created the category of 'slave' as means of punishing the idle and recalcitrant poor. As we have seen, the definition of 'vagrancy' was extended to cover any unemployed worker refusing to work for mere board, and anyone transgressing the provisions of the Act could become a slave for two years to the person informing on them. Those attempting to flee this punishment could be made slave for life. Parliament eventually repealed the law - not without a fight, since many still spoke of its advantages and continued to do so after its repeal - but the law itself is suggestive of the ways in which the categories of slave, servant, vagabond and worker were permeable.

Third, even when laws such as this were repealed, pockets of indentured labour remained. English law made the violation of many labour agreements punishable with imprisonment, and workers would be freed only after they had returned to their employers and completed the service in question. This service might last for a year, but would often be extended against the will of the worker as punishment for the original absence. This was transplanted into the colonial law of America, such that in both England and colonial America 'contractual labor' existed in varying degrees of 'unfreedom' (Steinfeld, 1991; Steinfeld, 2001). Indeed, well into the nineteenth century, runaway apprentices were still legally being hunted. This whole process of indentured labour was managed by irregular payment of wages such that workers could not leave their jobs without forfeiting several weeks or months of pay, a process that in real terms can feel like slavery. ${ }^{4}$

These forms and degrees of coerced ('unfree') and yet contractual ('free') labour inform us that by targeting the 'vagrant' or 'idle' poor, the manhunt was also de facto targeting the emerging working class. Put another way: the class of 'free' wage labour was forged through the manhunt, which was thereafter central to the political administration of formally free but materially coerced labour.

In a parallel process, the hunt was also central to strategies of accumulation and domination in the colonies. I have written elsewhere about the centrality of Captain

\footnotetext{
4 This latter point explains why as late as 1957 an 'Abolition of Forced Labour Convention' needed to be passed by international human rights movements in order to 'provide that wages shall be paid regularly and prohibit methods of payment which deprive the worker of a genuine possibility of terminating his employment'. The reason given was that such deprivation was 'analogous to slavery' (Office of the United Nations High Commissioner for Human Rights, 1957).
} 
Bernardo de Vargas Machuca's work on 'Indian militia' fighting and suggested that we might read it as perhaps the world's first extended treatment of pacification. Machuca argues that the military colonization of the Americas requires a kind of political violence in which the methods of those being pacified are adopted by the pacifiers. Local knowledge of crops and animals is necessary, but more important is the fact that the Indians fight like hunters. In this light Machuca advocates skirmishing, ambushing and fighting on the move, essentially as a permanent 'hunt' against the enemy 'hunters'. Through the adoption of 'Indian militia' ways of fighting, colonial warfare took the form of a continuous manhunt (Machuca, 2008; 2010; see Neocleous, 2011a). In so doing Machuca put his finger on a key aspect of the wars of colonial accumulation. More generally, the wars with the other 'Indians' found across the globe often took the form of manhunts intended to capture slaves for labour. Armed expeditions were carried out to hunt down fugitive slaves who had taken refuge in the woods, and the wars of extermination against those populations who resisted the conquest of their land were essentially manhunts (Hadden, 2003, 18, 50, 184; Steinfeld, 1991, 44; Chamayou, 2012, 30-1, 72; Gott, 2012, 124, 480-1).

Concerning the continent described by Marx as a preserve for the commercial hunting of black, Jean and John Comaroff write that warfare in South Africa took the form of nocturnal ambushes, 'shading into raiding'. Just as 'combat and commerce were closely interconnected, [so] too were warfare and the hunt, between which there was a strong metaphorical and material identity'. The war-hunt was a foray beyond the safe confines of the polity and territory and yielded significant proceeds in terms of goods, resources and labour (Comaroff and Comaroff, 1991, 164). The British Commander charged with defeating the Xhosa in Cape Colony, Colonel Graham, spoke of 'depriving them [the Xhosa] of the means of subsistence ... for which the whole colonial military force is constantly employed in destroying prodigious quantities of Indian corn and millet' and of 'taking from them the few cattle which they conceal in the woods'. But he spoke also of having to 'hunt them like wild beasts' (cited in Gott, 2012, 178) in order to achieve the goal.

Taking all this into account, it is no exaggeration to say that capital's conquest in the West was founded on a vast manhunt that continued across the Continents for almost four centuries: the hunting of blacks in Africa, the hunting of 'Indians' in the Americas and the East and West Indies, and the hunting of the poor across Europe. Capitalist accumulation was secured through the manhunt. As such, it simultaneously generated and engaged in whole series of related hunts, such as the hunt for pirates, the lynch-mob, the pogrom and the witch-hunt.

'The witch-hunt rarely appears in the history of the proletariat', notes Silvia Federici, but such hunts took place where the war of enclosures was most intense and then exported to the American colonies as a police measure. As a strategy designed to instill terror, destroy collective resistance, silence entire communities, and turn their 
members against each other', the witch-hunt was also a strategy of enclosure: 'class war carried out by other means'. Federici's point is that the witch-hunt, which reaches its peak between 1580 and 1630, needs to be understood in terms of the process of primitive accumulation, a simultaneous pacification of women to parallel the pacification of the working class (Federici, 2004, 163, 176, 220).

'The police is a hunting institution', notes Grégoire Chamayou $(2012,89)$, 'the state's arm for pursuit, entrusted by it with tracking, arresting, and imprisoning'. One can see this in the various technologies of police which have become so central to modern police forces: the police dog (Neocleous, 2011b), the psychological profile, the fingerprints, the photographs, the police helicopter, and now the drone as a technology for 'unmanning the manhunt' (Wall, this volume; Chamayou, 2011; Neocleous, 2013). But the tracking, arresting, and imprisoning are all traceable to the very origins of capitalist accumulation and the centrality of the hunt to those origins. We might say that the manhunt was nothing less than a core police power in the pacification of the proletariat as well as the accumulation of capital.

Pacification, it should be noted, enters political discourse in the late-sixteenth century, denoting 'a process or operation (usually a military operation) designed to secure the peaceful cooperation of a population or an area where one's enemies are thought to be active' (Oxford English Dictionary). The OED also proposes that to pacify is 'to reduce to peaceful submission'. In taking from the Roman tradition of imperial glory through military domination, in which pax implied 'pacification', 'pacification' was understood in terms of the verb 'pacificate', now obsolete but which in the sixteenth and seventeenth centuries meant 'to make peace'; the OED entry for 'peace-keeper' notes the emergence of the term in the very late-sixteenth century and 'peacemaker' just a little earlier. Playing on the constitution of internal order, 'pacification' quickly came to describe the creation of a certain kind of peace, order and security. Pacification, then, is a military act dressed up as the 'peace' of civil society. It was at the very same point historically that the category 'police' ('Policey', 'Policei', 'Polizei') became central to political thought, denoting the legislative and administrative regulation of the internal life of a community to promote general welfare and the condition of good order. Within this frame of good order, the key function of police was 'keeping the peace'. As Max Weber puts it, 'the increasing demand of a society accustomed to absolute pacification for order and protection ("police")' was a key driving force in the direction of the bureaucratic state and capitalist accumulation (Weber, 1978, 972).

Thus we might say that the invention of capitalism saw the invention of the police dream of society. The creation of the 'well-ordered police state' (Raeff, 1983) was a process of pacification. Capital and police dream of pacification: a dream of workers available for work, present and correct, their papers in order, their minds and bodies docile, and a dream of accumulation thereby secure from resistance, rebellion or revolt. 
Yet there is more to be said, for as much as hunting is a police power so hunting is also a practice of war, as our discussion of the colonies has already suggested. ${ }^{5}$ Historians of war have tended to identify three principal forms of land war: the pitched battle, the siege, and the raid. Our conceptions of medieval and early modern war tend to rely heavily on the idea of siege and our conceptions of modern war tend to rely heavily on the idea of a pitched battle, but both have a tendency to minimise the predominance of the raid in the history of warfare, as recent scholarship has shown. 'The most lethal and common form of warfare was the raid', notes Azar Gat $(2006,117)$. The raid, however, has historically taken the form of the manhunt (Whitman, 2012, 28), which is why Aristotle $(1996,19)$ describes war as a form of hunting: a hunt for human rather than animal prey. ' $M o s t$ warfare was at base a form of the hunt for human prey', notes James Whitman $(2012,35)$. 'When we survey the history of human warfare with a careful professional eye', he adds, what we overwhelmingly discover is 'not heroic confrontations between armed warriors in a "fateful day" of pitched battle but the brutal hunt for human prey, in which armed men turn their weapons on defenseless members of their own species' $(2012,26)$. 'The war pack originally emerged from the hunting pack', notes Canetti $(2003,192),{ }^{7}$ a process that amounts to guerrilla war: a radical dissymmetry in the weapons, a form of fighting which consists less of pitched battles and much more of a process of tracking down and raiding. This war as hunting and hunting as war took on a capitalist hue when the rising bourgeois class and its state powers applied it to the tracking down of the vagrant non-worker.

Capital's secret, then, lies in its ability to martial all the power the state can muster - manifesting itself variously as war power, as law power, as police power - in response to its own demand 'Let there be workers!', right down to its willingness to hunt down the labour it wants. Paraphrasing Aristotle's claim that 'the art of acquiring slaves ... [is] a

\footnotetext{
${ }^{5}$ In their account of capital and the 'war machine' Deleuze and Guattari $(1987,395)$ deny this, claiming that 'it is certain ... that war does not derive from the hunt'. Yet they make this claim solely on the conception of the hunt as a relation between man and animal, thereby completely overlooking the hunt as the relation between man and man and thus as a class relation.

6 It is worth noting the remarkable historical loop undertaken by the concept of 'raid'. The original meaning of 'raid' is 'a military expedition on horseback; a hostile and predatory incursion, properly of mounted men'. The word appears to have died out by the seventeenth century, but was revived again in the nineteenth century by when the horses had disappeared from the picture and the term refers to an invading troop or company'. In the twentieth century, the development of air power saw 'raid' connote 'an aircraft on a bombing operation', thereby giving us the concept of the 'air-raid' and, from there, given the role of air power as police power (Neocleous, 2013), it gets transformed into the 'police-raid'. And note that the 'dawn raid', so beloved by police because it targets people when they are least aware and active, is also Stock Exchange slang for an early morning operation to buy a substantial number of shares in a company, thereby cutting out the opportunities for competitors in the commercial war. In the concept of the 'raid', in other words, we find once again the nexus of ideas at the heart of pacification: war-police-accumulation.

7 The comment centres on a discussion of Canetti's arguments regarding the pack in Crowds and Power.
} 
species of hunting or war', we might say that the art of producing wage slaves is a species of hunting or class war. This is not just about the actual hunt, though it is certainly that, but is also very much about the modes of classification, lines of demarcation and processes of administration drawn within the bourgeois order by the ruling class in order to define who might be hunted (Chamayou, 2012, 2). And the question of 'who might be hunted?' always needs to be placed alongside another question: what are the obstacles to further accumulation? To end, we might explore this a little in the context of the 'security issue' of our time.

\section{Let There Be Accumulation!}

'I have ... ordered that the full resources of the Federal Government go to help the victims and their families and to conduct a full-scale investigation to hunt down and to find those folks who committed this act'. Thus spoke President George Bush on 11 September, 2001. Later that day and on the following day he was at pains to call the attacks on the World Trade Center an act of war, but one which required a response in the form of a hunt. 'Make no mistake: The United States will hunt down and punish those responsible for these cowardly acts' (Bush, 2001a; 2001b). Two years later, as the war on terror shifted to Iraq, Bush commented that 'all I know is we're on the hunt [for Hussein]. It's like if you had asked me right before we got his sons how close we were to get his sons, I'd say I don't know, but we're on the hunt' (2003a; 2005a). This wasn't just about Hussein, but was part of the nature of the war-police operation: 'We're at war in a different kind of war. It's a war that requires us to be on an international manhunt'. Bush could not stop himself: 'We're on the hunt' he insists again, elaborating further on other occasions by describing a 'global manhunt for terrorist killers' and 'an unrelenting international manhunt' (Bush, 2003b; Bush 2004a; Bush, 2004b). Zarqawi was talked about in the same language when he became the focus: 'Zarqawi understands that coalition and Iraqi troops are on a constant hunt for him as well' (Bush, 2005a).

Such formulations have been understood as part of Bush's inheritance of the standard Republican trope of the gunslinger and the ubiquity in the US of the image of social order taken from the Western, and there is of course some truth in this. 'Welcome to Injun country', is said to be the comment made by soldiers serving in Afghanistan and Iraq on meeting new arrivals there, exactly the same phrase as was used in Vietnam. 'The red-Indian metaphor is one with which a liberal policy nomenklatura may be uncomfortable', notes Robert Kaplan, 'but Army and Marine field officers have embraced it because it captures perfectly the combat challenge of the early 21 st century' (Kaplan, 2004). Hence the hunt for key individuals replicates the hunt for key Indians: the hunt for Bin Laden was codenamed 'Geronimo'. Beyond the individuals, the metaphor remains pervasive in American military discourse because it 'suggest[s] chaotic and dangerous 
territories that must be pacified, war against non-white peoples, guerrilla and terrorist forms of combat, and ultimate victory' (Porter, 2009, 44). Most of all, however, the metaphor refers back to earlier colonial wars and thus reveals the permanence of the process of primitive accumulation.

In this regard we need to treat the hunting of Bin Laden and Hussein as just one aspect of a much larger hunting operation. This took the form of a hunt for terrorists in general, which in turn folded into a hunt for an amorphous enemy: 'we hunt an enemy that hides in shadows and caves'; 'we are on the hunt for the enemy, capturing and killing the terrorists before they strike ... we're on the hunt for the enemy, and we're not going to rest until they've been defeated'; and on it went (Bush, 2001c; 2006; 2005b). This hunting took place not only in Iraq and Pakistan, but was also part of the domestic scene as it coincided with, played off and reinforced an even wider hunt for criminals. Three times in the space of three months in 2004 President Bush commented on the importance of law and police powers as mechanisms for hunting the criminal-enemy as well as the terrorist-enemy. 'The PATRIOT Act ... allows Federal law enforcement to better share information to track terrorists, to disrupt their cells, and to seize their assets ... If these methods are good for hunting criminals, they are even more important for hunting terrorists' (Bush, 2004c; 2004d; 2004e). This was also understood as part of a wider 'Call to Hunt for Terrorists' in which the broader citizen body was to be mobilized (Murphy, 2005).

This broadening out of the hunt suggests wider issues at stake beyond the trope of the gun-slinging law-enforcing sheriff. For a start, such hunting has come to dominate the scene of sovereign power in America. 'How do we organize the Department of Defense for manhunts?' asked Donald Rumsfeld (cited in Scarborough, 2004, 20), and within the US military and security elite the idea was taken seriously. One report written by two army Majors and an air force Captain noted that 'the fundamental question concerning manhunting is whether the United States government (USG) is properly organized to conduct manhunts? Currently, the USG has no central organization that oversees manhunting' (Marks, Meer and Nilson, 2005, 75). George A. Crawford, an intelligence and security officer with over 20 years experience at high level, developed an argument in a report from within the Joint Special Operations University and a paperback book concerning 'the viability of manhunting as a core element of American national security doctrine' (Crawford, 2008, 282; Crawford, 2009, 1, 7, 9, 34-40). A further document treats the manhunt as a link between Special Operations Forces and law enforcement agencies, arguing that 'both SOF and law enforcement have interests in finding people', that 'the notion of manhunting has considerable merit' for both war and 
police, and that 'for both SOF and LEAs ... the characteristics of manhunting are basically the same' (Alexander, 2010, 58-60). ${ }^{8}$

The arguments of Crawford and others situate contemporary security strategy within the long history of warfare and/as the manhunt. But then might we not do the same, only situating contemporary security strategy within the long history of class warfare? What is noticeable about the contemporary manhunt is that the wider this hunt gets - from named individuals, to terrorists in general, to criminals, to the enemies of order and security - the more it opens up the space for us to consider the war on terror through the logic of pacification. This renders it less a manhunt in the form of the Western and more a manhunt in the classical sense of war-police-accumulation; less a war on and hunt for those responsible for terrorist acts, and more war of and hunt for global accumulation. For although capital no longer hunts for workers in quite the same way as it once did during its early formation, it still demands 'Let there be accumulation!', and still uses all the means of violence at its disposal to meet this demand. In historicopolitical terms, then, the hunt for Hussein in 2003 and his capture in December of that year was of far less significance than a whole raft of other measures within which the hunting needs to be positioned. Take, for example, the revision of Iraq's patent law enacted just a few months after the hunt and capture of Hussein.

For generations, farmers in Iraq operated in an essentially unregulated, informal seed supply system, whereby farm-saved seed and the free innovation with and exchange of planting materials among farming communities was standard agricultural practice. Yet the Coalition Provisional Authority established after the invasion of Iraq changed the law (with Order 81), making it illegal for Iraqi farmers to re-use seeds harvested from new varieties registered under the law. As the GRAIN organization noted in an opinion piece on the war being waged against Iraqi farmers, 'the purpose of the law is to facilitate the establishment of a new seed market in Iraq, where transnational corporations can sell their seeds, genetically modified or not, which farmers would have to purchase afresh every single cropping season'. In other words, the historical prohibition of private ownership of biological resources was to be replaced by a new patent law allowing a system of monopoly rights over seeds, with the rights in question almost certain to be held by multi-national corporations (GRAIN, 2004, 1-2). This was then supported and sustained by the broader measures entrenched in the new constitution established for the country in October 2005, which requires that the state in Iraq manages the Iraqi economy in accordance with modern - that is, 'liberal' - economic principles and to ensure the development of the private sector. Such changes demand that we read the 'war on terror'

\footnotetext{
8 With 'live' police hunts becoming regular features on TV, the manhunt also now offers another moment of the spectacle of security, reinforcing points made elsewhere in this volume by McMichael, Saborio and Wall.
} 
through the wider frame of neoliberal strategy: what is important is the hunt for accumulation, not the hunt for Saddam.

From an anti-security perspective, what is most telling about the war on terror is not the ousting of dictators or the violation of liberty and law in the name of security and order, but the pacification of peoples, and this pacification takes place first and foremost through the separation of workers from the resources for anything like an alternative mode of being beyond capital. Remaining for the moment with the means of subsistence (or as the security-mongers like to call it, 'food security'), the generation of a new seed market in Iraq must be situated in the context of TRIPS (Trade-Related aspects of Intellectual Property Rights). Operating under the auspices of the World Trade Organization but pushed through by major corporations within the multi-national information industries and their lobbying group the Intellectual Property Committee, TRIPS enacts an ideology of intellectual property rights which presupposes that ideas and genetic material are commodities like any other, to be marketed as such and managed by monopolies through patent and copyright law. Resources once used by peoples on a collective basis become appropriated as property for accumulation, from the Indian neem plant now patented for oral hygiene use to the West African karité butter now appropriated by the cosmetics industry. For this process to work the legal status of the resources have to be changed from being the common property of indigenous communities to being the patented property of corporations; the 'intellectual commons' becomes private property, human need overridden by accumulation and profit.

This stress on intellectual property has become central to contemporary accumulation strategies, and this centrality is the reason why the figure once so widely feared and hated by the bourgeois class during the rise of capitalism, the pirate, has once more come to the fore. To put that another way, this is why piracy-hunting is once again all the rage. Because TRIPS is centrally concerned with intellectual property, it moves very quickly and easily between the patenting of certain products as medicine to the question of 'pirated' products under copyright. In so doing, the geopolitical problem of securing an accumulation regime increasingly reliant on intellectual property becomes bound up with the overwhelming hegemonic power of the concern with 'terrorism'. Hence the contemporary line, now seen in government documents and journalism everywhere, that 'Piracy is Terrorism'. Although such claims often refer to activities taking place in Somalia and elsewhere, and reinforce the idea that some states are outside the international legal order (viz., 'pirate states'), it is remarkable how frequently the claims also refer to the importance of intellectual property for accumulation in general.

The equivalence between piracy and terrorism gained legitimacy in 1995, when New York's Joint Terrorism Taskforce claimed that profits from counterfeit T-shirt sales

\footnotetext{
9 A quick internet search for this phrase offers over 6 million hits.
} 
helped fund the 1993 bombing of the World Trade Centre. But following 9/11 a wide range of organizations have naturalized the relationship between piracy and terrorism, and in September 2003 Interpol extended its list of organizations seen as security threats and suspected of using profits from pirated material. Chechen separatists and Northern Irish paramilitaries were added to a list which already included Al Qaeda, Hezbollah, Hamas, FARC, Albanian and Basque separatists, anti-Arroyo agitators in the Philippines, and the Cosa Nostra. As a consequence, the widespread assumption is that profits from pirated films and games funnel back to organizations which supposedly threaten our security (Govil, 2004, 380). A conference on 'Security Measures for Music' - the title being somewhat revealing of our times: even music is now a security issue - held by the Indian Music Industry in Chennai in 2003, was informed by a former police commissioner that music pirates in Europe, the US and Pakistan have strong links with terrorist organisations, and that rooting out music piracy was a means of countering terrorism. Thus we are told, for example, that pirated films sold in Canada help fund the LTTE and that pirated games sold in the UK help fund Al Qaeda (Rangaraj, 2003). The general story runs as follows:

They [the terrorists, the pirates] run what looks like legitimate businesses, travel to 'business meetings' in Frankfurt, Amsterdam, and New York, and pay fictional 'employees' with money that feeds and houses terrorist cells. They run computer manufacturing plants and noodle shops, sell 'designer clothes' and 'bargain basement' CDs. They invest, pay taxes, give to charity, and fly like trapeze artists between one international venture and another. The end game, however, is not to buy a bigger house or send the kids to an Ivy League school - it's to blow up a building, to hijack a jet, to release a plague, and to kill thousands of innocent civilians' (US Dept. of Transportation, 2003).

In the political imagination of the security state, the crime of piracy is apparently so profound that it is not close to terrorism, but actually is terrorism, in that it constitutes an attack on accumulation itself. The hunt for the terrorist is thus always already the hunt for the pirate, and vice versa, but what is once again obvious is that what is really at stake in such hunting is never this or that pirate but, rather, the pirate in general and thus accumulation in general: 'suffer pirates, and the commerce of the world must cease' (Newton, 1742, 2).

This process has therefore unsurprisingly been called the 'new enclosures' or the 'second enclosure movement', and is one of the reasons why there has been a resurgence of interest in 'primitive accumulation' as a category. Just as historical development of the 'old' or 'first' enclosures was crucial to accumulation and pacification, so the 'new' or 'second' enclosures reminds us of the fundamental role that intellectual property 
currently plays in international accumulation and thus of capital's constant demand: Let there be Accumulation! TRIPS thus needs to be set alongside other international arrangements such as NAFTA (the North American Free Trade Agreement), which allows the dumping of heavily subsidized food products by US-based corporations onto the markets of other countries within the Agreement. In Mexico alone this has led to the ripping from producers of an estimated $\$ 1$ billion a year in earnings and to the forcible dispossession of some 2 million farmers of their means of subsistence (and who, as migrants, thereby become a 'security problem' and who therefore have to be hunted down).

The pirate has always been interpellated as communis hostis omnium - 'the enemy of all mankind' - and the hunt for the pirate thereby easily legitimized. But the hunt for the pirate, as a criminal-enemy, and thus as a threat to both internal security and global order, has involved powers used in prosecuting both belligerents and criminals (Simpson, 2007; Heller-Roazen, 2009). The pirate, in other words, must be made to succumb to the war power and the police power. As we have seen, the exercise of such powers in the name of capital and to realise the demand for accumulation is the process of pacification.

The great secret of pacification is thus the very secret Marx reveals about capital: that wage labour must exist, must be constant and must be regular. In other words, if the

point of pacification historically was the use of political and legal power to manufacture wage-labour as the grounds of accumulation, this remains the case today. From the perspective of a politics of anti-security, the violent dispossession and proletarianization of peoples in the name of intellectual property rights and manifested through the hunt for the criminal-terrorist-pirate is the contemporary instantiation of systematic pacification. For both capital and the state, the hunting will never end.

\section{References}

Alexander, John, B. 2010. Convergence: Special Operations Forces and Civilian Law Enforcement, Joint Special Operations University Report 10-6.

Aristotle. 1996. The Politics, in The Politics and The Constitution of Athens, ed. Stephen Everson. Cambridge: Cambridge University Press.

Balibar, Etienne. 1970. 'The Basic Concepts of Historical Materialism', in Louis Althusser and Etienne Balibar, Reading Capital (1968), trans. Ben Brewster. London: New Left Books 
Beier, A. L. 1985. Masterless Men: The Vagrancy Problem in England 1560-1640. London: Methuen.

Bush, George W. 2001a. 'Remarks in Sarasota, Florida, on the Terrorist Attack on New York City's World Trade Center', 11 September, 2001.

Bush, George W. 2001b. 'Remarks at Barksdale Air Force Base, Louisiana, on the Terrorist Attacks', 11 September, 2001

Bush, George W. 2001c. 'Satellite Remarks to the Central European Counterterrorism Conference', Warsaw, 6 November, 2001.

Bush, George W. 2003a. 'President's News Conference', 30 July, 2003.

Bush, George W. 2003b. 'Remarks on Improving Counterterrorism Intelligence', FBI Headquarters, 14 February, 2003.

Bush, George W. 2004a. 'News Conference With Prime Minister Tony Blair', White House, 16 April, 2004.

Bush, George W. 2004b. 'President's News Conference, White House, 13 April, 2004.

Bush, George W. 2004c, 'Address Before a Joint Session of the Congress on the State of the Union', 20 January, 2004.

Bush, George W. 2004d. 'Remarks at the Port of Charleston, South Carolina', 5 February, 2004.

Bush, George W. 2004e. 'Remarks on the Anniversary of the United States Department of Homeland Security', 2 March, 2004.

Bush, George W. 2005. 'Remarks at a Swearing-In Ceremony for Michael Chertoff as Secretary of Homeland Security', 3 March, 2005.

Bush, George W. 2005b. 'Remarks on the War on Terror', Washington, 28 September, 2005.

Bush, George W. 2006. 'Remarks to the Foundation for the Defense of Democracies', George Washington University, 13 March, 2006. 
Canetti, Elias. 1972. 'Crowds and Power: Conversation with Elias Canetti', trans. Rodney Livingstone, in Theodor W. Adorno, Can One Live After Auschwitz? A Philosophical Reader, ed. Rolf Tiedemann (Stanford, CA: Stanford University Press, 2003,

Canetti, Elias. 1962. Crowds and Power, trans. Carol Stewart. London: Victor Gollanz.

Chamayou, Grégoire. 2011. 'The Manhunt Doctrine', Radical Philosophy 169: 2-6.

Chamayou, Grégoire. 2012. Manhunts: A Philosophical History (2010), trans. Steven Rendall. Princeton, NJ: Princeton University Press.

Comaroff, Jean and Comaroff, John. 1991. Of Revelation and Revolution, Vol. 1: Christianity, Colonialism, and Consciousness in South Africa. Chicago: University of Chicago Press.

Crawford, George A. 2008. Manhunting: Reversing the Polarity of Warfare. Baltimore: PublishAmerica.

Crawford, George A. 2009. Manhunting: Counter-Network Organization for Irregular Warfare, Joint Special Operations University Report 09-7.

Deleuze, Gilles and Guattari, Felix. 1987. A Thousand Plateaus: Capitalism and Schizophrenia (1980), trans. Brian Massumi. London: Athlone Press.

Engels, Frederick. 1975a. 'Speech at Elberfeld, 8 February, 1845', in Karl Marx and Frederick Engels, Collected Works, Vol. 4. London: Lawrence and Wishart.

Engels, Frederick. 1975b. The Condition of the Working Class in England, in Karl Marx and Frederick Engels, Collected Works, Vol. 4. London: Lawrence and Wishart.

Federici, Silvia. 2004. Caliban and the Witch: Women, The Body and Primitive Accumulation. New York: Autonomedia.

Foucault, Michel. 1997. Discipline and Punish, trans. Alan Sheridan. London: Allen Lane.

Foucault, Michel. 1996. 'Confining Societies' (1972), trans. Jeanine Herman, in Foucault Live: Collected Interviews, 1961-1984. New York: Semiotext(e). 
Foucault, Michel. 2006. History of Madness, trans. Jonathan Murphy and Jean Khalfa. London: Routledge.

Gat, Azar. 2006. War in Human Civilization. Oxford: Oxford University Press.

Geremek, Bronislaw. 1994. Poverty: A History, trans. Agnieszka Kolakowska. Oxford: Blackwell.

Gott, Richard. 2012. Britain's Empire: Resistance, Repression and Revolt. London: Verso.

Govil, Nitin. 2004. 'War in the Age of Pirate Reproduction', in Sarai Editorial Collective (ed.), Sarai Reader 2004: Crisis/Media. Delhi: Centre for the Study of Developing Societies.

GRAIN, 2004. Iraq's New Patent Law: A Declaration of War Against Farmers, 15 October, 2004. Available at http://www.grain.org/article/entries/150-iraq-s-new-patentlaw-a-declaration-of-war-against-farmers

Hadden, Sally E. 2003. Slave Patrols: Law and Violence in Virginia and the Carolinas. Cambridge, MA: Harvard University Press.

Heller-Roazen, Daniel. 2009. The Enemy of All: Piracy and the Law of Nations. New York: Zone Books.

Kaplan, Robert. 2004, 'It's Time to Remember the Lessons of the Indian Wars', Wall Street Journal, 21 Sept., 2004, reprinted at History News Network http://hnn.us/roundup/entries/7480.html

Locke, John. 1988. Two Treatises. Cambridge: Cambridge University Press.

Luxemburg, Rosa. 1913. The Accumulation of Capital, trans. A. Schwarzschild. London: Routledge.

Machuca, Bernardo de Vargas. 2008. Milicia Indiana (1599), trans. Timothy F. Johnson, in Captain Bernardo de Vargas Machuca, The Indian Militia and Description of the Indies. Durham: Duke University Press.

Machuca, Bernardo de Vargas. 2010. Defense and Discourse of the Western Conquests (1613), trans. Timothy F. Johnson, in Defending the Conquest: Bernardo de Vargas 
Machuca's Defense and Discourse of the Western Conquests, edited by Kris Lane. University Park, Pennsylvania: Pennsylvania State University Press.

Malesevic, Sinisa. 2010. The Sociology of War and Violence. Cambridge: Cambridge University Press.

Marks, Steven, Meer, Thomas and Nilson, Matthew. 2005. Manhunting: A Methodology for Finding Persons of National Interest. Monterey, CA: US Naval Postgraduate School.

Marx, Karl. 1972. Theories of Surplus Value, Vol. III. London: Lawrence and Wishart.

Marx, Karl. 1973. Grundrisse, trans. Martin Nicolaus. Harmondsworth: Penguin.

Marx, Karl. 1976. Capital: A Critique of Political Economy, Vol. 1, trans. B. Fowkes. Harmondsworth: Penguin.

Marx, Karl. 1977. 'The June Revolution, Neue Rheinische Zeitung, 29 June, 1848', in Karl Marx and Frederick Engels, Collected Works, Vol. 7. London: Lawrence and Wishart.

Marx, Karl and Engels, Frederick. 1984. The Manifesto of the Communist Party. In Collected Works, Vol. 6. London: Lawrence and Wishart.

Midnight Notes Collective. 1992. Midnight Oil: Work, Energy, War, 1973-1992. New York: Autonomedia.

Murphy, Dean E. 2005. 'Retirees Answer the Call to Hunt for Terrorists', New York Times, 5 May, 2005 - online.

Neocleous, Mark. 2000. The Fabrication of Social Order: A Critical Theory of Police Power. London: Pluto Press.

Neocleous, Mark. 2008. Critique of Security. Edinburgh: Edinburgh University Press.

Neocleous, Mark. 2010. 'War as Peace, Peace as Pacification'. Radical Philosophy 159: 817. 
Neocleous, Mark. 2011a. 'Security as Pacification'. In Anti-Security, edited by Mark Neocleous and George S. Rigakos. Ottawa: Red Quill Press.

Neocleous, Mark. 2011b. 'The Smell of Power: A Contribution to the Critique of the Sniffer Dog'. Radical Philosophy 167: pp. 9-14.

Neocleous, Mark. 2012. 'International Law as Primitive Accumulation; or, The Secret of Systematic Accumulation'. European Journal of International Law 23, no. 4: 94162.

Neocleous, Mark. 2013. 'Air Power as Police Power'. Environment and Planning D: Society and Space.

Neocleous, Mark and Rigakos, George. 2011. 'Anti-Security: A Declaration'. In AntiSecurity, edited by Mark Neocleous and George S. Rigakos. Ottawa: Red Quill Press.

Newton, Henry. 1742. Comments as member of the Admiralty, in 'The Trial of Joseph Dawson ...For Felony and Piracy at the Old Bailey, 19 October, 1696'. In A Complete Collection of State-Trials and Proceedings Upon High Treason, and Other Crimes and Misdemeanours, Vol. V. London.

Office of the United Nations High Commissioner for Human Rights. 1957. 'Abolition of Forced Labour Convention'. Available at http://www2.ohchr.org/english/law/abolition.htm

Porter, Patrick. 2009. Military Orientalism: Eastern War Through Western Eyes. London: Hurst and Co.

Raeff, Marc. 1983. The Well-Ordered Police State: Social and Institutional Change Through Law in the Germanies and Russia, 1600-1800. New Haven: Yale University Press.

Rangaraj, R. 2003. 'Music Piracy and Terrorism'. Available at http://www.holoflex.com/media/chennaionline.html

Scarborough, Rowan. 2004. Rumsfeld's War: The Untold Story of America's Anti-Terrorist Commander. Washington, DC: Regnery Publishing. 
Simpson, Gerry. 2007. 'Piracy and the Origins of Enmity'. In Time, History and International Law, edited by Matthew Craven, Malgosia Fitzmaurice and Maria Vogiatzi. Leiden: Martinus Nijhoff.

Steinfeld, Robert J. 1991. The Invention of Free Labor: The Employment Relation in English and American Law and Culture, 1350-1750. Chapel Hill: University of North Carolina Press.

Steinfeld, Robert J. 2001. Coercion, Contract, and Free Labor in the Nineteenth Century. Cambridge: Cambridge University Press.

US Dept. of Transportation. 2003. Transit Security Newsletter, No. 36. Available at http://transit-safety.volpe.dot.gov/security/newsletters/html/Vol36/Page2.asp

Weber, Max. 1978. Economy and Society. California: California University Press.

Whitman, James Q. 2012. The Verdict of Battle: The Law of Victory and the Making of Modern War. Cambridge: Harvard University Press. 